\title{
NPR2 wt Allele
}

National Cancer Institute

\section{Source}

National Cancer Institute. NPR2 wt Allele. NCI Thesaurus. Code C51566.

Human NPR2 wild-type allele is located within 9p21-p12 and is approximately $18 \mathrm{~kb}$ in length. This allele, which encodes atrial natriuretic peptide receptor 2 protein, plays a role in the mediation of receptor binding interactions of a variety of natriuretic peptides. 